\title{
EDUCATION AND NEO-COLONIZATION: A CRITIQUE OF ENGLISH LITERATURE CURRICULUM IN PAKISTAN
}

\author{
Monazza Makhdoom*
}

\begin{abstract}
This research study seeks to examine the study of the topics mentioned in Pakistani educational context and English literature being taught after the creation of Pakistan. An attempt has also been made to look into the cultural and socio-political dimensions of control which were established by the British colonist through the implementation of their language and literature in the subcontinent in 1835. Furthermore, Gramsci (1935) and Said's (1979, 1983) theoretical and conceptual models are used to describe the ongoing process of cultural hegemony, which is being carried on through educational institutions. This has been dealt with by attempting to discuss the present English curriculum at post graduate level with especial reference to Punjab University in the light of the research topic. The research aimed to find out how hegemony of the Western literature is perpetuated through education in Pakistan therefore; the theoretical and conceptual frameworks were investigated through a detailed library research. The theoretical analysis as well as the curriculum content selection was analyzed qualitatively, in order to highlight the role and importance of other literatures in English in the curriculum as other and indigenous cultural representations in education to neutralize and decentralize the Anglo centricity that exists in our present pedagogy of English literature in higher education.
\end{abstract}

Keywords: Neo-colonization, Anglo centricity, Eurocentricity, Western literature

\footnotetext{
* Lecturer: Department of English, College of Liberal Arts and Sciences, Foundation University
} 


\section{Introduction}

Independence from the British colonial oppression was a tremendous achievement in the history of colonization. Many former colonies of Britain raised question to the continued use of English language and literature. According to Ngugi (1986) the language issue is a very important key to the decolonization process. However, the approaches to the continued use of English in the colonies were not uniform, and there were many and clear differences between them. For example, even in the white settler colonies, the use of their own literatures in the English language curriculum is swamped with problems. Some of the problems have to do with the national identity, whereby the literatures of the white settler colonies, many of whose texts explore questions of identities that are distinct from the British or English identity, need to be taught in school and university, but are not found in the curriculum. The situation in non settler colonies is not very different. In fact, it may actually be stronger. Achebe (1975) believes that there is an authoritative link between literature and education as conceived in a broader context. Ngugi (1986) on the other hand suggested not to incorporate British literature and gave preference to other literatures of the world in the curriculum.

As Pakistan is also a former colony of the British Empire and major changes in the curriculum should have been addressed. However, one feels that policy changes are slow in Pakistani educational context to acknowledge more diverse cultural issues of our indigenous heritage and tradition and to implement programme of change.

The institution of education does not exist in isolation. English literature has its roots in a complex web of social relations of which it becomes an important part. In many ways it has a connection with bodies such as the state, with issues of gender, the social classes, ethnicity, economic system, politics and above all representation. Moreover, Literary education should be analyzed as to how it interacts with complex areas such as the various groups and social classes in the society. Therefore, regarding the prevailing social class in the society and its alliance with that social force, education can perform a broader role. Education can be liberating, critical, conservative, or closed, it may be subversive or suppressive it can also be emancipator. Education in a society has a prospective to be both, subversive or liberating. In this 
political context, it is important to note that as a social force English education frequently serves the interests of powerful groups in the society. For the prime reason that the state itself is more often than not a representative of powerful classes, and it is a matter of common observation that the education through English literature thus it imparts essentially the values and interests of the dominant classes. The mixed cultural attitudes towards learning English in Pakistan have been addressed to publicly by an ex-minister for education, Zobaida Jalal Khan (as cited in Saigol, 1993, 126):

It is my experience as minister of education that the position of the government in respect to English is not enviable. We may be satisfied with what we are doing but apparently we are the target of criticism from two sides - the sides that are working for and against English.

\section{Statement of the Problem}

The English literature curriculum at master's level needs rethinking in introducing and incorporating indigenous knowledge and content in its selection while revising curriculum which is primarily dominated by the Eurocentric model. Therefore, in order to educate and liberate the learners from purely dominant Western literature and criticism, there is a need of research to provide insight into indigenous knowledge in English curriculum.

The purpose of this study was to contest over the marginalization of our local and cultural component in English literature curriculum. The indigenous wisdom in the form of literature other than mainstream Western, will, in turn, accelerate the intellectual and academic self determination and shall facilitate in cultural decolonization.

\section{Context of the Study}

The context of the present study was English language and literature at post graduate level. The aim was to raise awareness and need about this particular study in educational context. 


\section{Objectives of the Study}

The study aimed to:

1. Critically review the official English literature curriculum and syllabi of the Punjab University from post colonial perspective.

2. Investigate how English literature, as a discourse of power, maintains hegemony over the periphery i.e. Pakistan.

3. Explore how dominant ideas, worldviews in a literary text can be resisted and made culturally relevant through education in literature pedagogy.

\section{Theoretical / Conceptual Framework}

The methodology of this research study was qualitative. The curriculum of English literature with reference to content selection has been qualitatively analyzed. The novels of the $18^{\text {th }}$ and $19^{\text {th }}$ century British origin have been discussed briefly by referring to the conceptual framework provided by Said $(1978,1994)$. The hegemonic activity of the literary text as well as the state has been studied from the theoretical framework provided by Gramsci (1971).

\section{Delimitation}

The study was delimited to remain focused only one genre from the curriculum of literature, as it was beyond the scope of this study to include all the genres being taught at master's level.

\section{Literature Review}

The literature has been reviewed from various perspectives. From educational perspective past and present Educational as well as Language policies compiled by Dodwell (1858-1918), Mansoor (2005) and Rehman (1996) have been considered. To investigate the role of English literature and language in establishing socio-political dimensions of control in the subcontinent, I referred to the detailed studies by Viswanathan (1997). For a holistic and panoramic understanding of English language and literature in establishing imperialistic attitudes in the colonized territories various writers were reviewed including: Talib (2002), Ngugi (1986), Alberto (2008), and Philipson (1992). For the purpose of understanding the crucial relationship of ideology, curriculum 
and literary studies theorist such as Eagleton (1983), Fairclough (1989) and Said $(1978,1994)$ have been primarily referred.

\section{English Literature and Curriculum: A Critique}

The British colonists in 1835 introduced their 'standard' English language and its literature in British India to control it intellectually and culturally. However, even after independence British political and ideological dominance in the form of English language continued as a dominant discourse and authority. It should have been dismantled to perpetuate national language and culture of the independent state. But, the successful survival of foreign rule (English) and its persistent dominance in the shape of English language and unaltered patterns of teaching literature in English curriculum in Post colonial Pakistan has been a contributing factor in perpetuating cultural hegemony of Eurocentric ideologies as apparently neutral and objective 'voices' of 'commonsense' (Gramsci, 1971).

One also observes that during the period of colonial domination, the role and function of English curriculum and usage may not have received astute critical review and contestation. Now, in what appears to be a time of 'neo-colonization' there is more critical awareness of its status as a means of control and of distribution of social and intellectual capital. The policy-makers, political bureaucrats, curriculum designers and learners and learning institutions in most governmental and nongovernmental organizations are increasingly embracing English as the official, the formal, and the instructional language in their everyday businesses (Rehman, 1996).

At the same time, the writers and critiques of postcolonial literature for example, Pennycook (1994), Ngugi (1986) and Ashcroft, Griffith \& Tiffiny (1995) also argue that the current usage and impositions of English language and literature in most global institutions re-establish colonial relations (or hegemonies) and would require more 'critical' awareness and scholarship. Similarly, Said (1994) whose conceptual framework on cultural imperialism was a prime inspiration for the present study, has provided the post colonial societies with a new agenda of studying literature in the universities. Said (1994) provides us with "Themes of Resistance Culture". According to Said and Fanon, recovering of geographical territory which is at the heart of decolonization stands for primary resistance. However, the period of secondary resistance begins with the period of 
geographical independence from the colonial masters. Said also advocates that it is important to come out of degradation of colonization and calls it "ideological resistance" (Said, 1994). Therefore, in order to ideologically liberate ourselves from the shackles of hegemonic patterns that still plague us, an urgent response through the medium of text is required, "where the formally native speaks on their free states and nation as part of a general movement of resistance and domination' (Said, 1994, 6).

\section{Does Curriculum Matter in Literary Education?}

In educational discourse of literary studies in a country like Pakistan one can question the importance of curriculum even at university teaching. One can also reflect on seemingly simple question such as removal of curriculum and the meaning of education. Moreover, can we think about some form of power, hegemony, foreign cultural domination, race, and representation, without considering curriculum? Among those countries which were once subjected to the British dominance, Pakistan is one example, English curriculum should have been the very pivot of our preliminary focus. It becomes relevant because what knowledge and skills allow and permit or fail to give access to educational criteria such as: what is taught to the learners in an existing cultural context about themselves in relation to others does matter. Secondly, what is being overlooked and what is explicit and what is implicit in the curriculum and the scheme of studies is also important to consider.

In today's post colonial era, the concerns about the role of cultural imperialism are heightened especially in the sphere of educational discourse. Similarly, the issues about the Euro-centricity in the curriculum is also seen as an act of imperialism (Said, 1994; Ngugi,1981, 1985) whereby imposition of one specific cultural traditions and values on communities who have different values is contested as being political. One feels that there is no one 'single model' but, curriculum considerations should take place as an ongoing part of the process of extending education and focusing on specific targets for example, English curriculum in literature at masters level from the year, 1981-1991 did not have the aims and objectives mentioned in the official document distributed by the University Grants Commission (National Academy of Higher Education, 1991). Even educational policies in the past do not address the issue of languages and humanities curriculum and what it intends to impart on sociological, and cultural and ideological level (Govt. of Pakistan, 1971). 


\section{Is the curriculum of English literature neutral in educational context?}

It is a matter of observation that curriculum does matter significantly in education. Various governments in so many countries spend a lot of time in curriculum reform and policy making. Similarly, to quote a few examples, in many nations curriculum reforms have been a vital agenda in policy making and cultural movements which are at the heart of cultural relativism, hegemony and issues of class, representation and gender. Thus, one can also question the huge body of academic text which delineates these prevalent issues on class and representation in relation to literature as a discourse which is ideological in nature.

And yet, it is a matter of observation that in this broad area of English literature, which involves reading and decoding. text, deconstructing and demystifying old canons and traditions, is often thought about as an ideologically content- free skill and is seldom given due relevance. The counterfeit argument is that what we chose in curriculum making and its practices bears significance in establishing what dignity and possibilities are rendered to 'our culture', 'our voice' and 'our representation'. Above all, what dignity pertains to marginalized groups, voices other than British in our scheme of studies. To quote an example, Said (1978) points out the hidden power structures of the West's hegemony over the non Western communities by overtly pointing out the stereotypical binary representations in British literary canons. Apparently, so called neutral issues should also be reconsidered in broader scale, because every knowledge can bring about change in individuals and their perceptions about the world and themselves, secondly curriculum is important because as Bernstein (1971:41) once said:

How a society selects, classifies, distributes and transmits and evaluates the educational knowledge it considers to be public, reflects both distribution of power and the principles of social control.

\section{English Literature Curriculum at Post Graduate Level}

It is a matter of observation that the curriculum for the university teaching of English literature in Pakistan since independence has long been traditionally associating itself with a strong syllabus devoted to Eurocentric content. One has also observed that the prescribed curricular 
course of all the four compulsory genres (drama, poetry, novel, criticism) in the study of English literature are primarily traditional English literature courses. The consumption of these courses perpetuate the colonial legacy of a single culture which is heavily loaded with western history, philosophy and ideological referencing to a larger extent. In Such a course outline, canonical texts such as Shakespeare or Marlow's play, Bacon's essay, Hardy, Jane Austen, Chaucer, Spencer and Pope's poetry form the core courses. And the traditional approach in literature pedagogy has been that of analysis of texts in terms of plot construction, character, theme and genre analysis. However, the English literature content can be made less "British" and less "Anglo centric" and more open to other writing in English from Pakistan as well as from other writings of the world which have been a former British colony. With such an insight the following analysis of the English literature curriculum is looked into and analyzed on two grounds in a hope to bring forth a more genuine and meaningful curricula in the future:

1. Are we still engaged in colonial mainstream western canon where as others (For example, Australia, Africa and even India) are attempting to disassociate and amend their curriculum? .

2. Why have we not been able to establish the centrality of indigenous Pakistani cultural values through literature in English curriculum?

\section{An analysis of English Curriculum from 1981-1992}

In the past years up till 2006, as mentioned earlier, the curriculum that has been approved, designed and implemented by the Board of Studies in English has been a strong advocate of traditional model English literature for master's classes.

One can also argue that the 'National' Curriculum Revision Committee (University Grants Commission; 1990, 1996, 2006) in Pakistan, has continued to endow the English language with undue powers hence suppressing and marginalizing the diverse historical indigenous cultural values and attitudes in literature that could have possibly been fostered in the students. For example, if we consider the course outline for the years 1981-1992 which is a compulsory genre in the English curriculum, Paper 3: the "Novel", two factors can be mapped out from its critical study; one observes that the course content that has been included for the reading of master's students is covering a span of ten years. This also means that for a long period of ten years what ever happened in the world of educational discourse with respect to literature 
has not been considered. For nearly ten years in the literature curriculum: novel syllabi, only included the following writers of English canons from traditional core course which is heavily classical in nature: Fielding, Thomas Hardy, Jane Austen, Joseph Conrad, Dickens, E.M Forster, and George Eliot.

The list of the prescribed texts being completely Anglo dominated, has incorporated nothing from outside other than the Eurocentric literature to bring about any "change" in the existing curriculum. The "change" (HEC, 2006) as it has been emphasized in the introduction of English curriculum document, has to be seen from the fact, that literature students in the fast moving political climate especially after $9 / 11$ episode and global challenges need to be aware of not only the language empowerment and its significance as a social reality in constructing meaning, but, as many critical writers see within the educational institutes, the potential to change society by producing critical individuals who could question, challenge and finally explode the pervasive myths, beliefs and assumptions. For this to happen two things are simultaneously required: how the literature content is taught at pedagogical level and secondly, exploited and passed on to the students.

Secondly, the most characteristic tenants of the post modern critical work seeks to question that European philosophy and literature that has held to be essentially true at an abstract or programmatic level like the studies on philosophical debates such as epistemology, metaphysics, logic, is in truth a contingent and a cultural construct which is historically specific and has often served the indirect and hidden function of empowering members of a dominant social group at the expense of 'Others' (Said, 1994). Therefore, to bring about a fundamentally revolutionary "change" in a society like Pakistan, it is imperative that different aspects of knowledge and literature to be made a part of the curriculum. Here one would advocate the indigenous and culturally relevant literature to be taught equally at par with the European or British literature.

\section{English Curriculum Revision: 1991}

In 1990, the National Academy of Higher Education; University Grants Commission revised the curricula of English for B.A and M.A Level classes. The revision for the curricula did not come up with anything new that could be incorporated considering Pakistani cultural needs and values. It is also surprising to note that the curriculum document could not 
frame any specific 'aims and objectives' for teaching literature at M.A Level. Unfortunately, it seems that in Pakistani's educational perspective the aims of teaching English literature are not clear. We belong to a specific culture, with a strong history of conquest as well as of being conquered and colonized by the British. Moreover, if the aim is to 'develop the ability to read different types of texts independently and effectively', then the literature written in English by Pakistani writers can also serve the purpose. To develop the reading skills a heavily loaded British classical syllabus is not fundamentally required.

Secondly, it is also imperative that language awareness be created among the educational stakeholders, because language is culturally constructed and it's forms impose various meanings on its users (Fairclough, 1989). Language has an impact also the way it functions. Since the class room practices remain teacher dominated, where teacher is the authority, and in most cases, the teachers adhere to Anglo dominated criticism and learning, the curriculum remains traditional not only in content but also in its goals. Thus, traditional literary education is seen to be presented as benign and politically 'neutral' and 'commonsense' (Gramsci, 1971).

\section{English Curriculum: Revision for the year 1996-2003}

A cross reference between the curriculum content of the 'official curriculum' for the year 1996-2003 and that of the Punjab University maintains a singular pattern with the exception of putting new names; Classics make up novel one, core course and inclusion of four British novelists is a part of novel 2 .

For example, paper 3 (Novel 1) comprises of the following novelist:

- $\quad$ Fielding,

- Jane Austen,

- G. Eliot,

- Charles Dickens,

- Thomas Hardy.

And the paper 3, (Novel 2) makes a list of the following writers;

- Joseph Conrad,

- Virginia Wolf,

- William Golding,

- Margaret Drabble,

- Paul Scot 
The curriculum as well as the new and revised syllabi selected by the Punjab University does not mention any relevant change within the perspective of Pakistani educational context as well as cultural demands. The future trend in the world shows a shift in the educational discourse, where multiple ideas like democracy, freedom and 'an awareness of critical thinking and the dark side of educational enterprise' are also in question. Saigol (1993:126) points out about the situation in Pakistan:

The thoughts on increasing global interdependence point towards the fact that education exported historically from the West to the formally colonized countries had specific goals which prevented it from being critical. Although the imperial context within which this education was imparted has long since vanished from the globe, its form, and style remain in post-colonial society and still strongly affect the forms of leadership that appear in these societies. The educational system inherited from the imperial masters, but stripped of its liberal content, ensures a connection of dependency with the West and precludes the development of indigenous cultural forms, styles and images which would have a liberating influence upon the polity.

The statement by Saigol (1993) can be held true for the English literature curriculum and its pedagogy in Pakistan as well. The revised curriculums reveal a homogeneity, and one feels that the study of English literature in Pakistani educational context still carries the imperatives, goals and forms of colonial times with an effect upon the society. The content has further undergone change in the next "national curriculum' revision for the 2003 (Revised curricula of English) as for the first time a writer from post colonial world "Achebe" has been incorporated in the syllabi. The second change that has been observed is the inclusion of Ali Ahmed's "Twilight in Delhi" which again remains to be a modernist writer from pre independence times. However, from 2003 till the new version of the curriculum, i.e. curriculum of 2006, the results of which are yet to be seen, the issue of Pakistani indigenous voice in the compulsory course of 'novel' remains unheard.

\section{Conclusions}

This research paper is addressed precisely to the issue of Euro centricity at the cost of our own cultural and ideological loss. Language, 
as Fairclough (1989) has asserted, is a 'loaded weapon' and the Study of English language and literature is not an innocent activity. The myth of transparency and superiority of English literature is questioned, criticized and rejected. Study of English literature in Pakistan is embedded in ideology, "English literature was introduced by the English to control the potential subversive element in the natives and to establish their cultural hegemony" (Viswanathan, 1997).

For decades it has been observed that no post colonial or Pakistani writer was made a part of the compulsory genres in the curriculum. The changes that have been brought about were minor and insufficient to meet the requirement of the majority who has a culturally different background. Secondly, the post colonial response in the form of critical literacy is also not seen to be a part of the curriculum. The content of the English curriculum in the Punjab University has been a replica of the dominant Eurocentric values. Moreover, the domination and hegemony of the Western discourse exists in the form of preponderance of British and American writers in the literature syllabi. We need to create our own English curriculum and teaching materials to teach literature utilizing our own indigenous traditions and wisdom. Literature and its study is a crossing point between language, society, culture and ideology. It depends upon a cultural society to decide what is beneficial and relevant for them historically, psychologically and culturally. As Said (1978:25) has reiterated that we as 'third world' nations cannot afford to ignore the hegemony of English 'as the strength of the Western cultural discourse, a strength too often mistaken as merely decorative or "superstructural". Thus, the major problem is the uncritical consumption of hierarchy of literature as knowledge in educational context and therefore the post colonial educational structure emerges as the target of criticism. 


\section{BIBLIOGRAPHY}

Achebe, Chinua. (1975). Morning yet on creation day garden city. NY: Double day.

Ashcroft, Bill, Griffith, Gareth, and Tiffin, Helen. (1989). The empire writes back: Theory and practice in post colonial literatures. London and New York: Routledge.

Bernstein, Basil. (1977). Class, codes, control. Vol. 3. New York: Routledge.

Eagleton, Terry. (1983). literary theory: An introduction. Great Britain: Blackwell Publisher Ltd.

Fairclough, N. (1989). Language and power. London: Longman.

Fairclough, N. (1992). Critical language awareness, London, New York: Longman.

Government of Pakistan (1971). National educational policy. Islamabad: Ministry of Eduction.

Gramsci, A. (1971). Selections from the prison note books (edited and translated by Q. Hoare, G.Nowell-Smith). Lawrence \& Wishart.

Higher Education Commission (1990, 1996, 2006). Revised English curriculum. Islamabad: National Academy of Higher Education.

Ngugi, Wa, Thiongo. (1986). Writing against neo-colonialism. Vita Books.

Isani, latif. (2003). Report on English curricula; higher education in Pakistan. A historical and futuristic perspective. Islamabad: National Book Foundation.

Pennycook, A.D. (1994). The cultural politics of English as in international language. London, New York: Longman.

Philipson, Robert. (1992). Linguistic imperialism. Delhi: Oxford University Press.

Rehman, Tariq. (1996). Language and politics in Pakistan, Karachi: Oxford University Press. 
Said, Edward. (1978). Orientalism. USA: Vintage Books.

Said, Edward. (1994). Culture and imperialism. London: Vintage.

Saigol, Rubina. (1993). Educational: 'Critical perspectives'. Lahore: Progressive Publishers.

Talib, Ismail, S. (2002). The language of postcolonial literature: An introduction. London: Routledge.

University Grants Commission (1991). Revised curricula of English for B.A./B.Sc. and M.A. Levels. Islamabad: National Academy of Higher Education.

Viswanathan, Gauri. (1990). Masks of conquest: Literary studies and the British rule in India. London: Faber and Faber. 